Total Word Count of Manuscript (including Abstract, References, Figures and Tables) $=6121$

\title{
Integrating External Costs with Life Cycle Costs of Emissions from Tertiary Treatment of Municipal Wastewater for Reuse in Cooling Systems
}

Authors: Ranjani B. Theregowda ${ }^{\mathrm{a}}$, Radisav Vidic ${ }^{\mathrm{b}}$, Amy E. Landis ${ }^{\mathrm{c}}$, David A. Dzombak ${ }^{\mathrm{d}}$, and H. Scott Matthews ${ }^{\mathrm{e}}$

${ }^{a}$ Civil/Environmental Engineer, Transtech Engineering Consultants, Inc., 8808 Centre Park Drive, Columbia, MD 21045. Cell: (631)316-2677, Fax: (410)-730-1803 E-mail: rtherego@transtecheng.com

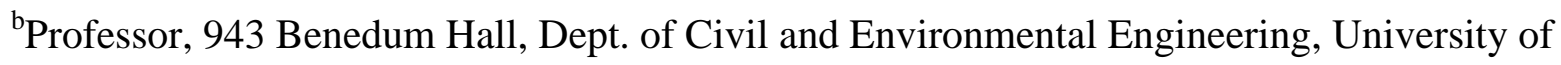
Pittsburgh , Pittsburgh, PA 15261. E-mail: vidic@engr.pitt.edu

${ }^{c}$ Associate Professor, School of Sustainable Engineering and Built Environment, Arizona State University, Tempe, AZ 85287. E-mail: Amy.Landis@asu.edu

${ }^{\mathrm{d}}$ University Professor, PH118, Dept. of Civil and Environmental Engineering, Carnegie Mellon University, 5000 Forbes Avenue, Pittsburgh, PA 15213. E-mail: dzombak@cmu.edu ${ }^{\mathrm{e}}$ Professor, PH123A, Dept. of Civil and Environmental Engineering / Engineering and Public Policy; Research Director, Green Design Institute, Carnegie Mellon University, 5000 Forbes Avenue, Pittsburgh, PA 15213. E-mail: hsm@cmu.edu

\begin{abstract}
Tertiary treatment is needed to render secondary-treated municipal wastewater usable in power plant cooling systems. Various tertiary treatment options exist to provide different levels of water
\end{abstract}


quality. This paper integrates life cycle inventory emissions from a life cycle assessment approach with direct costs to determine the optimal treatment alternative based on costeffectiveness and environmental sustainability. The costs of damage due to air emissions released during construction and operation of tertiary treatment alternatives were estimated using a hybrid based approach and were converted to external damage costs. Greenhouse gas emission $\left(\mathrm{CO}_{2}\right.$ eq.), acidifying gas emission $\left(\mathrm{SO}_{2}\right.$ and $\left.\mathrm{NO}_{\mathrm{x}}\right)$, and particulate matter $\left(\mathrm{PM}_{2.5}\right)$ emission unit costs were obtained from a Social Carbon Costs study, and cost factors from the Air Pollution Emission Experiments and Policy model were used to determine the total costs of emissions. The sum of average air emissions impact costs for the selected treatment processes were found to be between $5-8 \%$ of the total costs for tertiary treatment. Accounting for the external air emission costs provides a measure to assess the relative environmental costs of tertiary treatment

options for reuse of treated municipal wastewater in cooling systems. Environmental costs of other emissions to air, water and land, as well as benefits stemming from offsetting freshwater withdrawal by reusing treated effluent in power plant cooling systems were not included in the analysis.

\section{Introduction}

Secondary treated municipal wastewater (MWW) reused as makeup water for cooling systems at thermoelectric power plants has been investigated to reduce withdrawal of freshwater for cooling, and to decrease water contamination and withdrawal-related impacts on aquatic life (Li et al., 2011). Although secondary wastewater is a reliable and easily accessible resource, its higher contaminant concentrations relative to freshwater increase the scaling, corrosion, and bio- 
fouling control challenges of managing cooling water quality in recirculating cooling systems (Vidic and Dzombak, 2009). These challenges however can be resolved with advanced treatment of MWW prior to reuse in power plant cooling systems (Li et al., 2011; Vidic and Dzombak, 2009).

Selecting an appropriate level of tertiary treatment of MWW prior to reuse in a recirculating cooling system is an optimization problem. Advanced tertiary treatment processes for industrial water reuse applications are generally chosen based on economic feasibility and effluent quality requirements; rarely is the level of treatment to be imparted decided based on environmental inventory emissions or the economic consequences of those emissions. Construction and operation of advanced or tertiary treatment systems incur not only significant capital and operation and maintenance $(\mathrm{O} \& \mathrm{M})$ costs, but also lead to consumption of resources such as energy, coal for activated carbon and chemicals, that need to be taken into account when selecting a treatment strategy for MWW reuse (Theregowda et al., 2014).

Extraction of raw materials and production of equipment, chemicals and energy required for tertiary treatment release environmental emissions (such as greenhouse and acidifying gases and particulate matter) that are largely unexamined due to lack of incentives (e.g., credits to reduce consumption of treatment chemicals) to study and quantify these environmental emissions. Previous studies have made efforts to evaluate the net impact of treatment technology created in the pursuit of stringent water quality objectives (Antonucci and Schaumburg, 1975). Tools and/or methods devised to estimate the direct and indirect costs (Hydromantis, 2011), energy and 
resource consumption (Racoviceanu et al., 2007; Pasqualino et al, 2010; Tillman, 1998) and air emissions (Stokes and Horvath, 2010; Meneses et al., 2010; Pasqualino et al, 2009 \& 2010; Ortiz et al., 2006; Beavis and Lundie, 2003; Bagley, 2000; Roeleveld et al., 1997) associated with wastewater treatment have been developed. These studies have identified energy consumption, chemical manufacturing, sludge handling and disposal to be the main contributors to costs and environmental emissions (Pasqualino et al, 2009).

While there has been some interest in quantifying emissions related to construction and operation of wastewater treatment facilities, previous studies have not made an attempt to integrate the trade-offs and relationships between direct costs and environmental impacts of designs of tertiary treatment processes. For example, negligible tertiary treatment with intensive chemical conditioning can be inexpensive in terms of direct costs as minimal capital cost is required for treatment infrastructure, but the air emissions released due to increased consumption of conditioning chemicals and the impacts on the condenser due to degraded cooling water quality can be high. Neither the internal nor external economic aspects of such design decisions are within the scope of life cycle assessment (LCA) methodology, nor are they addressed by existing LCA tools. Apart from leaving the trade-offs and relationship between life cycle costs (LCC) and LCA uncharacterized, the consequences of separating LCC from LCA are that it limits the influence and relevance of LCA as a decision making tool, and the economic relevance for companies may be missed when cost analyses neglect LCA scope and findings (Norris, 2001). 
External costs are the monetized costs imposed on the society, due to direct and indirect damages caused by pollutants emitted during the manufacture of a product or rendering of services, which are not paid by the producers or the consumers nor considered in production or consumption decisions (NRC, 2010). Integration of external environmental and human health costs with economic costs is one approach toward a welfare-based measure of pollution output for any industrial process. One study on the environmental accounting for pollution in the U. S. economy (Muller et al., 2011) showed that the sewage treatment sector had air pollution damages higher than the value added by its service which was because of the lack of means to measure valuable non-market services in the national accounts. Although services for the sewage treatment industry are accounted for by the costs of production such as sewage fees, landfill tipping fees for sludge disposal, and land application costs for biosolids disposal, these fees fail to account for some of the non-market services and impacts, e.g., the external costs resulting from air emissions (Muller et al., 2011). Though this study does not attempt to provide measures for all non-market services and impacts of the tertiary wastewater treatment processes considered, it does make an effort to determine the economic consequence of specific air emissions released during construction and operation of tertiary treatment processes used to treat MWW for reuse in cooling systems. This analysis provided a means of assessing relative environmental impact of the various tertiary treatment options considered.

A total cost assessment tool completed by a collaborative effort of ten multinational companies and the American Institute of Chemical Engineers' Center for Waste Reduction Technologies defined five cost types: 1) direct, 2) indirect, 3) contingent, 4) intangible and 5) external costs 
(Norris, 2001). The direct costs include the capital investment, labor, raw material and waste disposal; indirect costs include overhead; contingent costs include fines and penalties, property damage and personnel injury liabilities; intangible costs include difficult to measure costs such as customer loyalty, work wellness, corporate image, union and community relations and; external costs are costs borne by the society (CWRT, 1999).

The objective of this study was to integrate life cycle cost estimates and life cycle inventory emissions calculated for various MWW tertiary treatment options in terms of monetary cost to aid in selection of a cost-effective and environmentally sustainable approach for tertiary treatment of MWW. Total costs in this study integrated the first (direct) and last (external) type of costs among the five cost types described above. After calculating the environmental costs for the air emissions, the costs were adjusted to 2009 U.S.Dollars $/ \mathrm{m}^{3}\left(\mathrm{USD} / \mathrm{m}^{3}\right)$ and then added to the life cycle conceptual costs obtained from the life cycle costing $\left(\mathrm{LC}^{3}\right)$ model estimates. The sum of the above mentioned costs represent the combined direct and external costs of tertiary treatment (in $2009 \mathrm{USD} / \mathrm{m}^{3}$ ) normalized for a given loading rate of the treatment plant.

The annual external costs due to greenhouse gas emissions (ton $\mathrm{CO}_{2}$ eq.), acidifying gas emissions $\left(\mathrm{kg} \mathrm{SO}_{2}\right.$ and $\left.\mathrm{kg} \mathrm{NO}_{\mathrm{x}}\right)$ and particulate matter emissions $\left(\mathrm{kg} \mathrm{PM}_{2.5}\right)$ from construction (fabrication of treatment infrastructure and equipment) and operation (energy, chemical and other supplies production) of MWW tertiary treatment alternatives were estimated using a hybrid LCA approach and external unit damage cost factors (in 2010 USD/ton or 2002 USD/kg). The effects of other emissions to air, water and land, as well as benefits stemming from reduced 
freshwater withdrawal for cooling systems were not estimated due to lack of established cost factors for those emissions.

\section{Methodology}

The total cost assessment for construction and operation of tertiary treatment processes involved extraction of life cycle cost (LCC) estimates and life cycle inventory (LCI) emissions from the LCC and LCI analyses performed previously for the various treatment processes considered (Theregowda et al., 2013 \& 2014), followed by the determination of cost factors for emissions averaged across the country. The external impact costs were discounted or inflated to the year 2009 and then added to the LCC estimates to obtain the total costs (in $2009 \mathrm{USD} / \mathrm{m}^{3}$ ).

The secondary and tertiary treated water quality from FTMSA used for design of tertiary treatment units and the MWW tertiary treatment alternatives considered in this study and for which the integration of LCC and LCI was conducted are listed in Table 1 (Vidic and Dzombak 2009; Theregowda et al., 2013) and Table 2 (Theregowda et al., 2013), respectively. Direct use

of river water (RW) with filtration as cooling water makeup was also evaluated to provide a benchmark for the tertiary treatment costs. All the tertiary treatment processes considered included addition of chemical conditioners after treatment, with the doses varied based on effluent quality. Benefits and impacts of reusing minimally treated secondary municipal wastewater in the cooling system, and the recommended level of tertiary treatment and dose of chemical conditioners to be applied for suitable reuse in cooling systems have been considered in 
choosing the six tertiary treatment alternatives selected for this study (Hsieh et al., 2010; Choudhary et al., 2012; Liu et al., 2012).

The system boundary for this study, shown in Figure 1, included the tertiary treatment units, chemical conditioning agent additions, and transport of treated effluent from the treatment site to the point of reuse. The functional unit was the treatment capacity for which the processes were designed, i.e., 7.75 MGD, the quantity of make-up water required by the recirculating cooling system of a 550 MW pulverized coal-fired power plant (U.S.DOE, 2007).

\subsection{LC L $^{3}$ Model Cost Estimates}

Life cycle cost estimates (in $2009 \mathrm{USD} / \mathrm{m}^{3}$ ) were calculated using the $\mathrm{LC}^{3}$ model (Theregowda et al., 2013), a public domain 'conceptual' cost model which provides first-stage cost estimates within the conceptual cost estimation accuracy range of $15-40 \%$ as defined by International Association for the Advancement of Cost Engineering (Westney, 1997). In the LC ${ }^{3}$ model, annual-cost estimates are calculated as the sum of the recurring costs (RC), also known as operation and maintenance costs, and the non-recurring costs (NRC), otherwise known as capital costs, and converted to an annual cost basis. For the purpose of this study, NRC estimates include annualized infrastructure construction costs and the costs of pumps, motors, auxiliary mechanical and digital equipment. While using LCC as inputs to the LCI model, NRC estimates were considered to be distributed over the service life of the equipment or treatment plant life commonly assigned, i.e., 25 years for concrete infrastructure, 10 years for pumps and mechanical equipment and 15 years for the digital control equipment. For direct cost estimates, NRC was 
considered to be the amortized capital costs with a capital recovery factor of $12 \%$ (de Neufville, 1990) over the service life (25 years) of the treatment plant.

\subsection{Life Cycle Inventory Emissions}

LCI emissions were estimated from annual estimates from the $\mathrm{LC}^{3}$ cost estimating model for individual treatment units along with the quantity of operational chemicals, activated carbon, and energy; these data were used as inputs to economic input-output (EIO-LCA) (CMU, 2012) and a process-based LCA (PRé Consultants, 2008) model to estimate total LCI emissions for the system (Theregowda et al., 2014). The annualized cost estimates from the LC $^{3}$ model were referenced to 2009 U.S. dollars (USD), but later converted to 2002 USD input for synchronization with the EIO-LCA model (Theregowda et al., 2014).

Inventory of emissions associated with activated carbon, chemicals for treatment and conditioning, energy and delivery distance for chemical transport were obtained from the ecoinvent v2.2, U.S.LCI and Franklin databases summarized in Table 3. The life cycle environmental emissions included in the study inventory were greenhouse gases (GHG), sulfur dioxide $\left(\mathrm{SO}_{2}\right)$, nitrogen oxides $\left(\mathrm{NO}_{\mathrm{x}}\right)$, and particulate matter $\left(\mathrm{PM}_{2.5}\right)$ emissions to the atmosphere. Equivalent $\mathrm{GHG}$ emissions ( $\mathrm{kg} \mathrm{CO}_{2}$ eq.) were calculated using the IPCC 2007 100a characterization method (IPCC, 2007). Sulfur dioxide ( $\left.\mathrm{t} \mathrm{SO}_{2}\right)$, nitrogen oxides $\left(\mathrm{t} \mathrm{NO}_{\mathrm{x}}\right)$ and particulate matter $<2.5$ micron size $\left(\mathrm{t}^{\left.\mathrm{PM}_{2.5}\right)}\right.$ pollutant emissions were estimated using the output inventory obtained from the U.S.EPA Aerometric Information Retrieval System (AIRS) data 
(U.S.EPA 1989 \& 1993) in EIO-LCA, and the aforementioned ecoinvent, U.S.LCI and Franklin databases in SimaPro.

\subsection{Estimation of External Costs for Emissions}

A number of studies have been conducted to try to quantify the environmental impact costs of air emissions. Using data on the social costs of production, attempts have been made to make integrated "green" national accounts by adjusting them for environmental (and other) costs [32](Matthews and Lave, 2000; Nordhaus and Tobin, 1972; Daly and Cobb, 1989). A summary of social cost of carbon (SCC) updated based on the latest peer-reviewed version of the integrated assessment models used to estimate SCC revealed the three 2010 SCC average values (in 2007 USD) to be $\$ 11$ (discount rate $=5 \%), \$ 32($ discount rate $=3 \%)$ and $\$ 51$ (discount rate $=$ $2.5 \%$ ) and the $95^{\text {th }}$ percentile value to be $\$ 89$ (discount rate $=3 \%$ ) (U.S. Government IWG, 2013). The average $\$ 32$ (2007 USD)/ton cost was implemented in this study for emissions of $\mathrm{CO}_{2}$ eq.

For the other air emissions considered in this study, average costs were used from the APEEP (Air Pollution Emission Experiments and Policy) model (Muller and Mendelsohn, 2007). APEEP estimates the marginal (incremental) human health and environmental damages corresponding to marginal emissions of $\mathrm{PM}_{2.5}, \mathrm{VOC}, \mathrm{NO}_{\mathrm{x}}, \mathrm{NH}_{3}$, and $\mathrm{SO}_{2}$ on a dollar-per-ton basis at the county level (Muller et al., 2011; U.S.BLS, 2012). APEEP estimates the damages stemming from emissions at nearly 10,000 sources in the contiguous U.S. Damages include adverse effects on human health, reduced yields of agricultural crops and timber, reductions in 
visibility, enhanced depreciation of man-made materials, and damages due to lost recreation services. APEEP employs the results from numerous, peer-reviewed studies that apply these methods to value the physical effects of air pollution. It then evaluates emissions at different release heights.

To estimate the mean value of air pollutants, the APEEP model incorporates assumptions which introduce errors to the external cost estimates. Evaluation of these errors was beyond the scope of this study. The assumptions in APEEP include:

1) Cost estimates are accounting measures and not measures of economic welfare. The economy has many existing distortions other than those from air pollution—such as taxes, distortions from market power, and other externalities — and existing accounts do not attempt to incorporate those.

2) The model includes only the impact of air pollution and excludes other externalities such as those involving water, soil, and radiation.

3) The uncertainties in the external cost factors are particularly large for the value of mortality risks, the relationship of this value to age, the mortality effect of fine particulates, and the social cost of $\mathrm{CO}_{2}$ emissions (Muller et al., 2011).

In this study, APEEP cost estimates of $5.70 \mathrm{USD} / \mathrm{kg} \mathrm{SO}_{2}, 1.60 \mathrm{USD} / \mathrm{kg} \mathrm{NO}$ and $11.40 \mathrm{USD} / \mathrm{kg}$ $\mathrm{PM}_{2.5}$ for mid-level point sources (effective height between 250 and 500 meters) were used to assess emissions associated with tertiary treatment of MWW. County based weighted average 
APEEP cost factors determined for the U.S. was used for this study (Mashayekh et al., 2011). The external cost estimates were adjusted to the year 2009 based on dollar value inflation (19.3\% from 2002 to 2009 and $3.5 \%$ from 2007 to 2009) rates (U.S.BLS, 2012).

Due to accounting of spatial variability in the cost factors, the uncertainty introduced to the external costs is estimated to be very high. This uncertainty can be reduced if the spatial location of the input inventory production or use is specified by an approximate regional boundary i.e., rural or urban location and by accounting for the $5^{\text {th }}$ and $9^{\text {th }}$ percentile values for the external costs than the entire range of factors (which can include outliers or higher or lower extremes). To study the rural and urban only differences three alternate scenarios were analyzed as provided in Supplemental Material Appendix A, Figure A-1 to Figure A-3.

\subsection{Assumptions}

Assumptions made while converting air emissions released during construction and operation of tertiary treatment units to monetary damages were as follows:

1) The conventional air emission cost factors were taken as average values across the U.S. since specific locations for the treatment plant and the production of materials for construction and operation of the plant were not provided.

2) Emissions were assumed to be released mainly during production of materials required for the treatment process, and so the height for release of emissions was assumed to be mid-level (250500 meter from the ground) and from point sources. 
3) Constructing a constant-price time series would require time series for all cost parameter values and defining price indexes for each of the cost parameters (Muller and Mendelsohn, 2007) which were beyond of the scope of this study. Hence the external cost estimates were inflated to the year 2009 based on dollar value inflation (19.3\% from 2002 to 2009 and 3.5\% from 2007 to 2009) rates.

4) Emissions on-site at the tertiary treatment plant were assumed to be negligible compared to the emissions released during production of material inputs off-site and hence not considered in this study.

\section{Results and Discussion}

Prior to evaluation of the integrated direct and external costs of tertiary treatment alternatives, it is useful to examine the variability of the marginal damage cost factors. Such an analysis provides insight into the range of values that can be used to account for the external damage costs with spatial and temporal variation and subjectivity included in measuring the marginal damage due to a given set of inventory emissions.

Table 4 shows the different unit costs of external (or social) damages obtained from the literature (Matthews and Lave, 2000) and the APEEP model [36] for each inventoried air emission in terms of 1992 USD and 2002 USD (except for $\mathrm{CO}_{2}$ eq. for which 2010 USD values are shown).

Figure 2 shows the variation (range for U. S. counties) of cost factors between peer-reviewed studies. Also, from values presented in the Table 4, it may be seen that there is a significant increase in the dollar-per-ton values from 1992 to 2002 for all inventory emissions, which may 
be due to inflation in market goods (the loss of which is used to evaluate non-market services) or due to increased awareness in acknowledging the damages caused from air emissions released.

$\mathrm{PM}_{2.5}, \mathrm{SO}_{2}$ and $\mathrm{CO}_{2}$ eq. emissions values across the country vary widely for mid-level point sources as seen in Figure 2. $\mathrm{NO}_{\mathrm{x}}$ emissions show the minimum value to be negative, although its range of variation was relatively small. The average dollar-per-ton cost factors used in this study were close to the 5\% percentile costs shown in Figure 2 of the range for all emissions considered here, which is well justified by the literature sources and hence uncertainty analysis was not considered in this study (Mashayekh et al., 2011).

Results of the marginal damage costs and the integrated costs calculated using average dollarper-ton cost factors are shown in Figures 3 and 4, respectively. The margin bars (indicated with error bars) in Figures 3 and 4 show the range of costs calculated using the maximum and minimum cost factors from peer-reviewed literature. Figure 3 splits the costs for individual emissions per treatment alternative to examine the individual allocation of emissions of the total external costs calculated. The GHGs were primary contributors of impact costs for all alternatives except for $\mathrm{MWW} \_\mathrm{pH}$, wherein the $\mathrm{SO}_{2}$ emissions allocated to the manufacture of sulfuric acid was higher than the GHG emissions. MWW_NSF and MWW_NFG have noticeably high marginal external damage costs because of the three-tiered treatment infrastructure, electricity for aeration, addition of moderate conditioning and treatment chemicals, and regeneration of spent carbon. Among the two-tiered treatment alternatives, MWW_NF has lower external costs compared to the MWW_SF, because the latter alternative 
requires regular dosing of chemicals during tertiary treatment. RW and MWW_F have lower marginal damage costs since they involve only sand filtration $(\mathrm{F})$ as a tertiary treatment step, followed by addition of higher doses of chemical conditioners, to which a major portion of the existent emissions costs can be allocated.

Among emissions, though $\mathrm{PM}_{2.5}$ has high average unit costs, the overall costs of those emissions for the treatment units was estimated to be low because the quantity of $\mathrm{PM}_{2.5}$ released is much lower compared to other emissions. On the other hand, though GHGs were relatively emitted in much higher amounts, since their cost factors were not very high, their impact costs remain moderate. But, when the maximum cost factor is used, the external costs range high for GHG and low for the other three pollutants corresponding to the cost factors range listed in Table 4.

Figure 4 illustrates the total annual cost (in $2009 \mathrm{USD} / \mathrm{m}^{3}$ ) which is the sum of direct and impact related costs of emissions. The average impact costs of GHGs, acidifying gas emissions and particulate matter $(<2.5$ microns in size $)$ emissions vary between $5.3-7.2 \%$ of the total annual costs, with higher impact costs for MWW_NSF, followed by MWW_NFG, MWW_SF and then MWW_pH. Considering the maximum unit cost factors that can be used to determine the maximum impact costs as seen in the upper margin of the cost bar (indicated with error bar) in Figure 4, the maximum impact costs would be in the range of $45-70 \%$ of the total annual costs, which is almost equal to the direct costs incurred from tertiary treatment alternatives.

\section{Conclusions}


Integration of external costs of emissions with direct costs of construction and operation for various tertiary treatment alternatives for secondary treated municipal wastewater (MWW) was conducted. Accounting for damages caused by the release of air emissions along with the direct economic costs can help balance the external damage and the value added by a particular service, such as tertiary treatment to provide water that can be reused in power plant cooling. The attempt to account for impact costs due to release of greenhouse gases, acidifying gas emissions and particulate matter emissions in this study provides an aid to selecting a treatment alternative. From a perspective of the total costs incurred from tertiary treatment of MWW for reuse in power plant cooling systems, a treatment alternative can be selected based on both direct costs and environmental impact costs. A cost-benefit analysis could be carried out by analyzing the ratio of the costs vs. benefits which provides a distinct value that represents the total marketable services costs to the total non-marketable services and impacts. To further expand the study with a complete environmental sustainability and cost-benefit analysis, environmental costs from other emissions to air, water and land, as well as benefits stemming from offsetting freshwater withdrawal by reusing treated effluent in power plant cooling systems need to be examined.

The results of this study indicate that three-tiered treatment alternatives such as MWW_NSF and MWW_NFG, with regular chemical addition for treatment and conditioning and/or regeneration for tertiary treatment, tend to increase the impact costs and in turn the overall costs of tertiary treatment, even though their percent contribution to the total annual costs was moderate to low. RW and MWW_F alternatives with a single level of tertiary treatment have lower impact costs, but the contribution of impact costs to overall annual costs is higher than all other treatment 
alternatives, indicating that these alternatives were less cost-effective when the impact costs were integrated. MWW_NF and MWW_SF alternatives with two-tiered tertiary treatment have moderate external impact costs with moderate infrastructure and chemical conditioner dosing, which makes them (especially the former alternative) better treatment alternatives from the environmental impact perspective since they contribute to the lowest environmental damage from emissions.

\section{Acknowledgements}

This work was supported by the U. S. Department of Energy through NETL-DOE grant (DENT0006550). The views and opinions of authors expressed herein do not necessarily state or reflect those of the United States Government or any agency thereof. The authors thank Yeganeh Mashayekh, Aranya Venkatesh, Mahbuboor Choudhury, Shih-Hsiang Chien and Wenshi Liu for helpful suggestions in the work.

\section{References}

Antonucci, D. C. and Schaumburg, F. D. (1975) Environmental effects of advanced wastewater treatment at South Lake Tahoe. Journal of Water Pollution Control Equipment, 47 (11), 2694-2701.

Bagley, D. M. (2000) Life cycle analysis of municipal wastewater treatment. $6^{\text {th }}$ Environmental Engineering Specialty Conference, CSCE, Vol. 2, 437-443. 
Beavis, P. and Lundie, S. (2003) Integrated environmental assessment of tertiary and residuals treatment - LCA in the wastewater industry. Water Science and Technology, International Association on Water Pollution Research. 47 (7-8), 109-116.

Choudhury, M. R., Hsieh, M. K., Vidic R. D. and Dzombak, D. A. (2012). Corrosion Management in Power Plant Cooling Systems Using Tertiary-Treated Municipal Wastewater as Makeup Water. Corrosion Science, Vol. 61, 231-241.

CMU (2012). Economic Input-Output Life Cycle Assessment (EIO-LCA) US 2002 (428) model [Internet], Carnegie Mellon University Green Design Institute. Available from: <http://www.eiolca.net/> (Accessed 25 May 2012).

CWRT (1999). Total Cost Assessment Methodology, Center for Waste Reduction Technologies, American Institute of Chemical Engineers, New York, NY.

Daly, H. E. and Cobb, J. B. (1989). For the Common Good: redirecting the economy toward community, the environment, and a sustainable future; Beacon Press: Boston, MA.

de Neufville, R. (1990). Applied Systems Analysis: Engineering Planning and Technology Management. McGraw-Hill, Inc; New York.

Hsieh, M. K., Li, H., Chein, S. H. Monnell, J. D., Chowdhury, I., Dzombak, D. A. and Vidic, R. D. (2010). Corrosion Control When Using Secondary Treated Wastewater as Alternative Makeup Water for Cooling Systems, Water Environment Research, Vol. 82, 2346-2356

Hydromantis, Inc. (2011) CapdetWorks Product Overview. User Manual. Available at: http://www.hydromantic.com/CapdetWorks.html. (Accessed 7 May, 2012) Dept. of Civil and Environmental Engineering, University of Pittsburgh 
Intergovernmental Panel on Climate Change (IPCC) (2007). Climate Change 2007: The Physical Science Basis. Contribution of Working Group I to the Fourth Assessment Report of the Intergovernmental Panel on Climate Change [Solomon, S., D. Qin, M. Manning, Z. Chen, M. Marquis, K.B. Averyt, M.Tignor and H.L. Miller (eds.)]. Cambridge University Press, Cambridge, United Kingdom and New York, NY, USA.

Li, H., Chien, S., Hsieh, M.K., Dzombak, D.A. and Vidic, R.D. (2011) Escalating Water Demand for Energy Production and the Potential for Use of Treated Municipal Wastewater. Environmental Science \& Technology, 45(10), 4195-4200.

Liu, W., Chein, S. H., Dzombak, D. A. and Vidic, R. D. (2012) Mineral Scaling Mitigation in Cooling Systems Using Tertiary-Treated Municipal Wastewater. Water Research, 46(14), 4488-4498.

Mashayekh, Y., Jaramillo, P., Chester, M., Hendrickson, C. T. and Weber, C. L. (2011). Costs of Automobile Air Emissions in U.S.Metropolitan Areas. Transportation Research Record: Journal of the Transportation Research Board, No. 2233, Transportation Research Board of the National Academies, Washington, D.C. 120-127.

Matthews, H. S., and Lave, L. B. (2000). Applications of Environmental Valuation for Determining Externality Costs. Environmental Science and Technology, 34(8), 1390-1395.

Meneses, M., Pasqualino, J. C., and Castells, F. (2010) Environmental assessment of urban wastewater reuse: Treatment alternatives and applications. Chemosphere, Vol. 81, 266-272.

Muller, N. Z., and Mendelsohn, R. O. (2007). Measuring the Damages from Air Pollution in the U.S.Journal of Environmental Economics and Management, 54(1), 1-14. 
Muller, N. Z., Mendelsohn, R. and Nordhaus, W. (2011) Environmental Accounting for Pollution in the United States Economy. The American Economic Review 101, 1649 - 1675.

National Research Council (NRC) (2010). Committee on Health, Environmental, and Other External Costs and Benefits of Energy Production and Consumption and National Research Council. Hidden Cost of Energy: Unpriced Consequences of Energy Production and Use. National Academies Press, Washington, D.C.

Nordhaus, W. and Tobin, J. (1972). In Economic Growth; National Bureau of Economic Research General Series 96E; Columbia University Press.

Norris, G. (2001) Integrating Life Cycle Cost Analysis and LCA. International Journal of LCA 6(2), 118-120.

Ortiz, M., Raluy, R. G., Serra, L. and Uche, J. (2006) Life cycle assessment of water treatment technologies: wastewater and water-reuse in a small town. Desalination, Vol. 204 (1-3), 121-131.

Pasqualino, J. M., Meneses, M., A. and Castells, F. (2009) LCA as a decision support tool for the environmental improvement of the operation of a municipal wastewater treatment plant. Environmental Science and Technology, Vol. 43 (9), 3300-3307.

Pasqualino, J. M., Meneses, M., A. and Castells, F. (2010) Life cycle assessment of urban wastewater reclamation and reuse alternatives. Journal of Industrial Ecology Vol. 15 (1), 49 $-63$.

PRé Consultants (2008) SimaPro database manual methods library v 2.2. Available from: www.pre.nl (Accessed 18 January, 2012). 
Racoviceanu, A. I., Karney, B. W., ASCE, M., Kennedy, C. A. and Colombo, A. F. (2007) Life cycle energy use and greenhouse gas emissions inventory for water treatment systems. Journal of Infrastructure Systems, Vol. 13 (4), 261-270.

Roeleveld, P. J., Klapwijk, A., Eggels, P. G., Rulkens, W. H. and van Starkenburg, W. (1997) Sustainability of municipal wastewater treatment. Water Science and Technology, Vol. 35 (10), 221-228.

Stokes, J. R., and Horvath, A. (2010) Supply-chain environmental effects of wastewater utilities. Environmental Research Letters, IOP Publishing. Available at: doi:10.1088/1748$9326 / 5 / 014015$

Theregowda, R.B., Hsieh, M.K., Walker, M.E., Landis, A.E., Abbasian J., Vidic, R.V., Dzombak, D. A. (2013). Life Cycle Costs to Treat Secondary Municipal Wastewater for Reuse in Cooling Systems. Journal of Water Reuse and Desalination. Available at: doi:10.2166/wrd.2013.078

Theregowda, R., Vidic, R., Dzombak, D. A. and Landis, A. E. (2014), Life cycle impact analysis of tertiary treatment alternatives to treat secondary municipal wastewater for reuse in cooling systems. Environ. Prog. Sustainable Energy. doi: 10.1002/ep.11938

Tillman, A., Svingby, M. and Lundstöm, H. (1998) Life cycle assesssment of municipal waste water systems. Int. J. LCA, Vol. 3 (3), 145-157.

U.S.BLS (2012). Monthly consumer price index. U. S. Bureau of Labor Statistics, Division of Consumer Price Indexes, Washington, DC.

U.S.Department of Energy (DOE) (2007). Cost and Performance Baseline for Fossil Energy Plants, Volume 1: Bituminous Coal and Natural Gas to Electricity. Report Number: 
DOE/NETL-2007/1281, A report of the U.S.Department of Energy, National Energy Technology Laboratory, Pittsburgh, PA.

U.S.EPA (1989). US Environmental Protection Agency - Aerometric Information Retrieval System User's Guide (Vol.I), Research Triangle Park, NC: USEPA, Office of Air Quality Planning and Standards, Technical Support Division, National Air Data Branch.

U.S.EPA (1993). US Environmental Protection Agency- Aerometric Information Retrieval System (AIRS). Vol 2. Office of Air Quality Planning and Standards, Research Triangle Park, NC: Environmental Protection Agency, 1993.

U.S.Government, Interagency Working Group on Social Cost of Carbon (2013). Technical Support Document: - Technical Update of the Social Cost of Carbon for Regulatory Impact Analysis - Under Executive Order 12866.

Available from: http://www.whitehouse.gov/sites/default/files/omb/assets/inforeg/technicalupdate-social-cost-of-carbon-for-regulator-impact-analysis.pdf . <Accessed June 17 2014>

Vidic, R. D. \& Dzombak, D. A. (2009) Reuse of Treated Internal or External Wastewaters in the Cooling Systems of Coal Based Thermoelectric Power Plants. Final Technical Report submitted To U. S. Department of Energy, National Energy Technology Laboratory, Pittsburgh, PA.

Westney, R. E. (1997). The Engineer's Cost Handbook - Tools for Managing Project Costs. Marcel Dekker, Inc., NewYork, Ch. 2. 


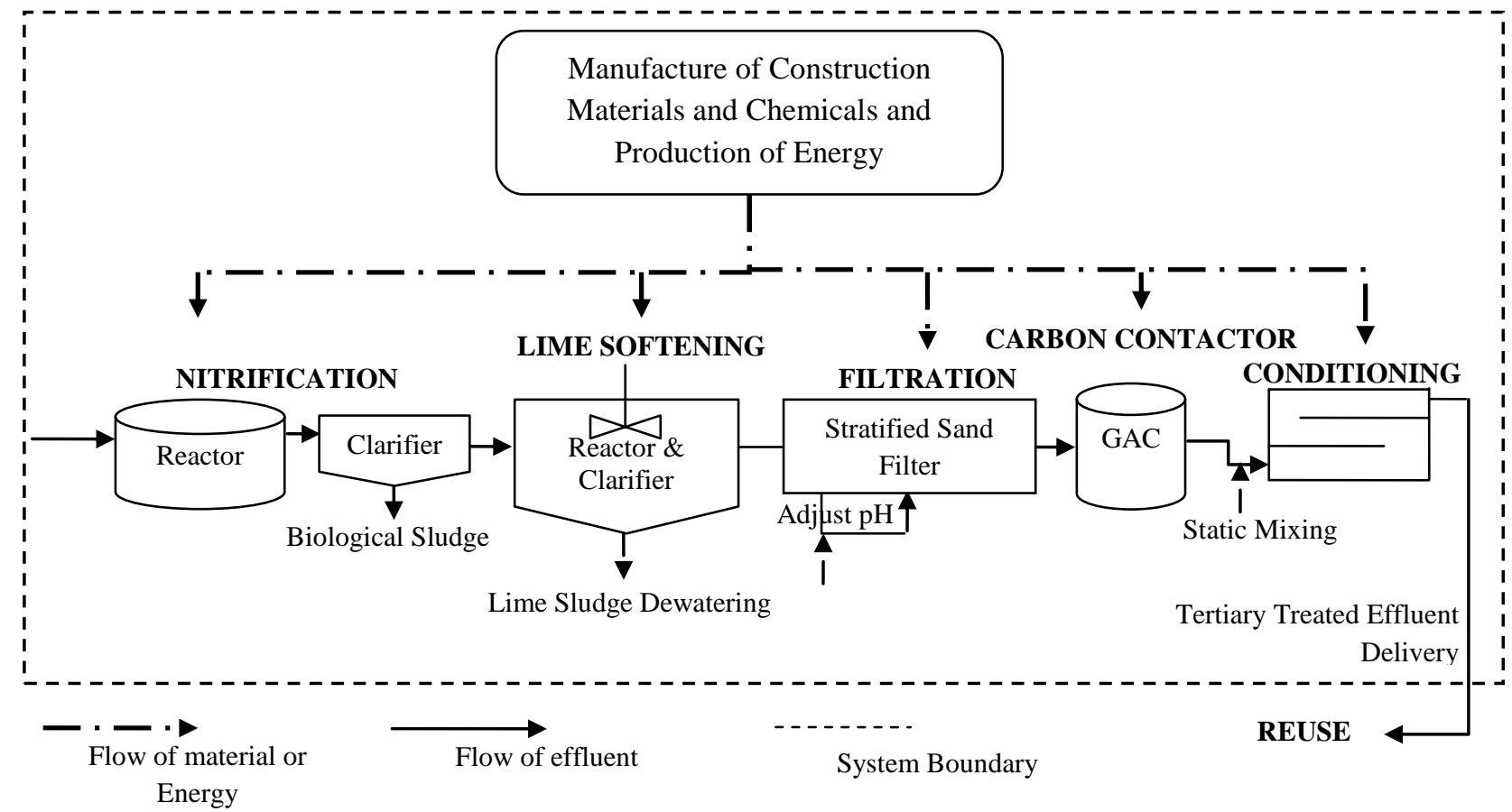

Figure 1. Flowchart of the study system. System boundary for the life cycle assessment (LCA) evaluation of tertiary treatment units is indicated as a dashed line. Treated effluent delivery from the tertiary treatment plant to the thermoelectric power plant is included (Theregowda et al., 2014). 


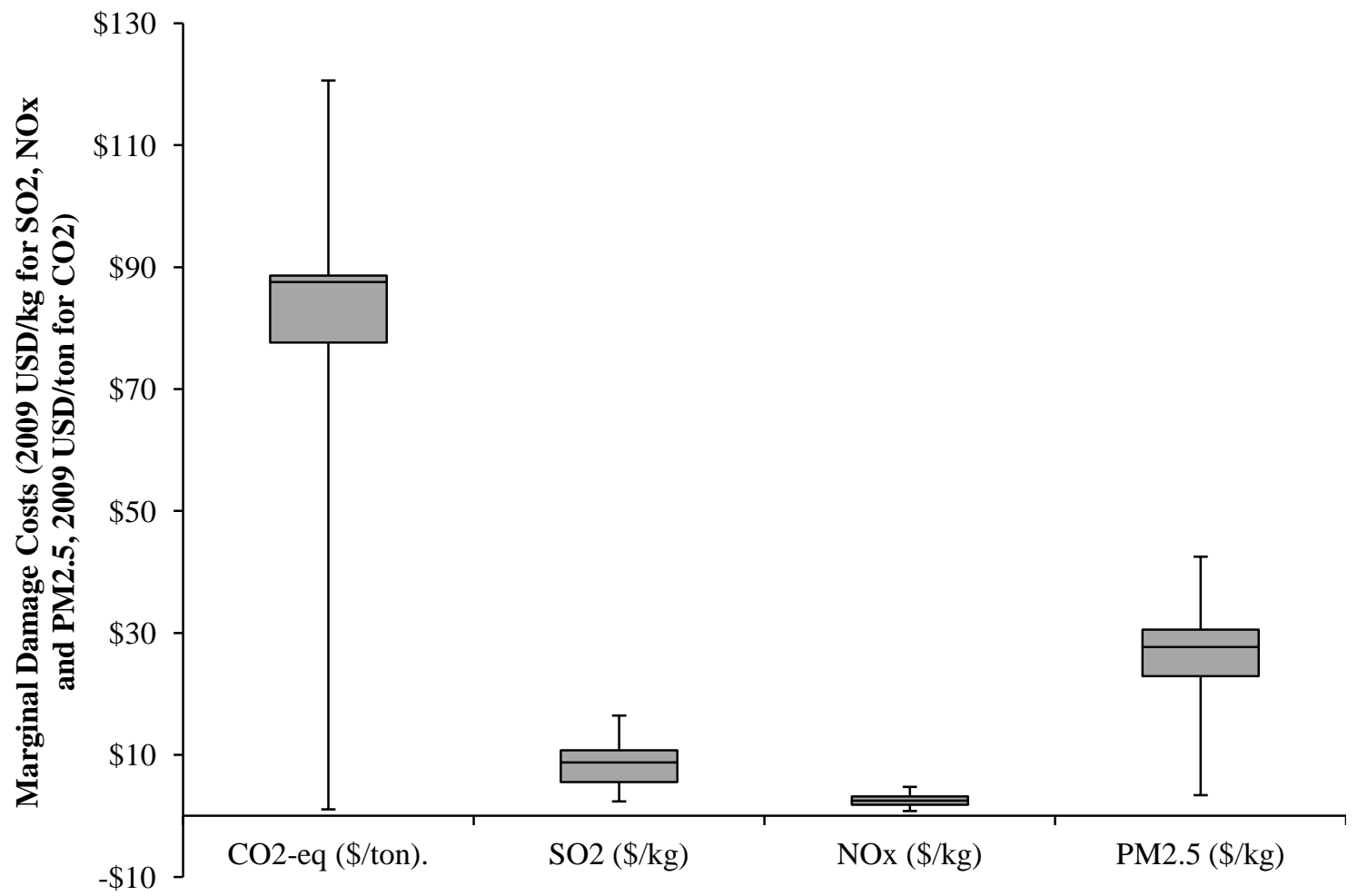

24 Figure 2. Range of marginal damage costs (in $2009 \mathrm{USD} / \mathrm{kg}$ for $\mathrm{SO}_{2}, \mathrm{NO}_{\mathrm{x}}$ and $\mathrm{PM}_{2.5}, 2009$ USD/ton for $\mathrm{CO}_{2}$ ) the U. S. taken from social cost of carbon (SCC) study for greenhouse gases $\left(\mathrm{CO}_{2}\right.$ eq. $)$, from APEEP for mid-level pollutants emissions of acidifying gases $\left(\mathrm{SO}_{2}\right.$ and $\left.\mathrm{NO}_{\mathrm{x}}\right)$

27 and particulate matter $\left(\mathrm{PM}_{2.5}\right)$. Error bars represent $5 \%$ and $95 \%$ of the damage estimates provided in Table 3. 


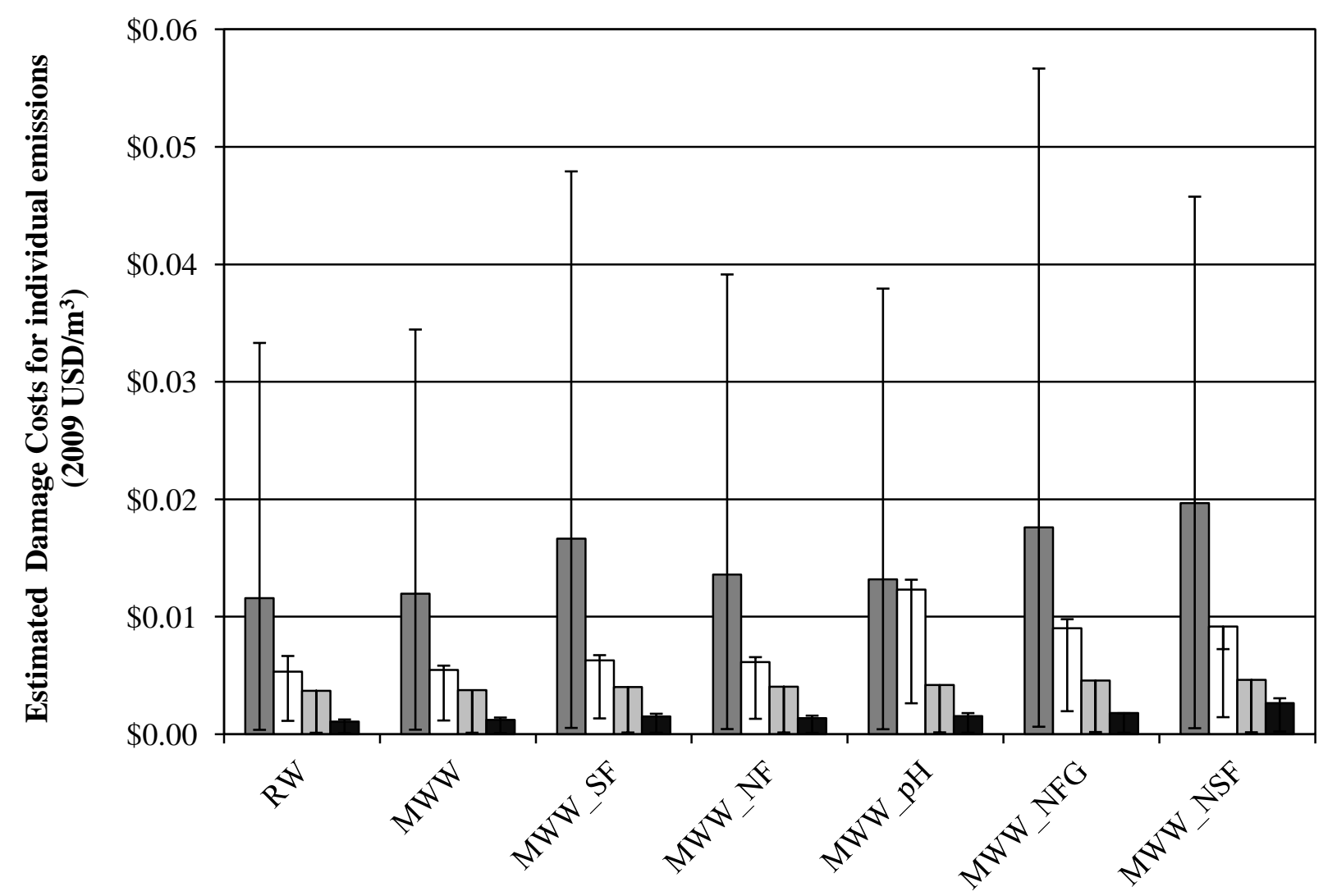

39

Figure 3. Estimated environmental costs (in $2009 \mathrm{USD} / \mathrm{m}^{3}$ ) of individual air emissions for tertiary treatment alternatives. Average external damage costs per $\mathrm{t} \mathrm{CO}_{2}$ eq. $=\$ 32$, per $\mathrm{kg} \mathrm{SO}_{2}=$

$42 \$ 11.20$, per $\mathrm{kg} \mathrm{NO}_{\mathrm{x}}=\$ 2.26$ and per $\mathrm{kg} \mathrm{PM}_{2.5}=\$ 33$ were used for estimation of impact costs

Legend: $\square \mathrm{CO}_{2}$ eq. damage costs, $\square \mathrm{SO}_{2}$ damage costs, $\square \mathrm{NO}_{\mathrm{x}}$ damage costs, $\square \mathrm{PM}_{2.5}$ damage

Note: $\mathrm{kgal}=$ kilo gallon, Nitrification $(\mathrm{N})$, Lime Softening $(\mathrm{S}), \mathrm{pH}$ adjustment $(\mathrm{pH})$, Filtration $(\mathrm{F})$, Chemical

45

management (C) for anti-corrosive agent -Tolytriazole (TTA), anti-scaling agent - Polymaleic Acid (PMA) and biocide - Monochloramine (MCA) 


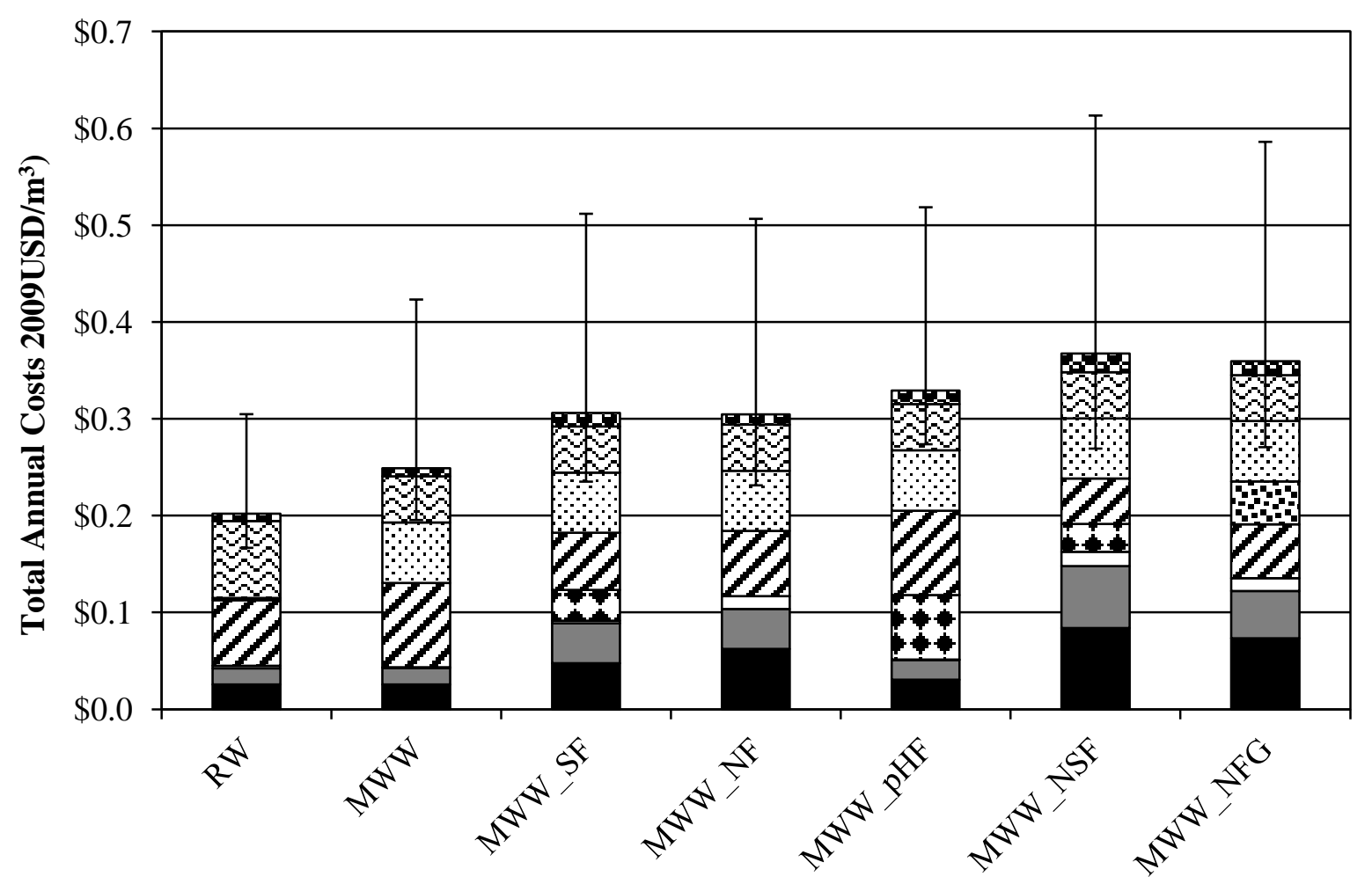

Figure 4. Total annual costs (in $2009 \mathrm{USD} / \mathrm{m}^{3}$ ) of tertiary treatment alternatives, inclusive of direct and external costs. Average external damage costs per $\mathrm{t} \mathrm{CO}_{2}$ eq. $=\$ 32$, per $\mathrm{kg} \mathrm{SO}_{2}=$ $\$ 11.20$, per $\mathrm{kg} \mathrm{NO}_{\mathrm{x}}=\$ 2.26$ and per $\mathrm{kg} \mathrm{PM}_{2.5}=\$ 33$ were used for estimation of impact costs

Legend: $\square$ Construction of treatment infrastructure, $\square$ Labor and maintenance, $\mathbb{Z}$ Chemical manufacture and transport for treatment, $\square$ Electricity for operation, Water supply infrastructure and pumping, 运讶 Raw source water costs, Damage costs, Chemical manufacture and transport for conditioning

Note: 1)The costs presented in the graph are base treatment costs that include nominal charges for the secondary treated wastewater and supply fees for 10 mile delivery distance and additional chemical management, but do not include additional service or taxes. Secondary treated raw municipal wastewater cost was assumed to have a base value of approximately $0.18 \mathrm{USD} / \mathrm{kgal}$ and was added to the tertiary treatment costs when comparing total costs with city water $(\mathrm{CW})$ and river water $(\mathrm{RW})$ costs.

69 2) $\mathrm{kgal}=$ kilo gallon, Nitrification $(\mathrm{N})$, Lime Softening ( $\mathrm{S})$, $\mathrm{pH}$ adjustment (pH), Filtration (F), Chemical management (C) for anti-corrosive agent-Tolytriazole (TTA), anti-scaling agent - Polymaleic Acid (PMA) and biocide - Monochloramine (MCA)

72 3) Established RW and CW rates were obtained from state or regulatory agencies (Delaware River Basin Commission, 2011. Minnesota Department of Natural Resources, 2011, WMP Advisory Committee - LCRA Raw Water Rates, 2011 and Black \& Veatch, 2010). 
Table 1. Secondary and tertiary treated water quality from FTMSA used for design of tertiary treatment units (Vidic and Dzombak 2009; Theregowda et al., 2013)

\begin{tabular}{|c|c|c|}
\hline Parameters (mg/L unless noted) & Secondary & Tertiary \\
\hline Calcium $(\mathrm{Ca})$ & 41.5 & 39.7 \\
\hline Magnesium (Mg) & 10.7 & 9.8 \\
\hline Manganese (Mn) & 0.32 & 0.34 \\
\hline Ammonia-N $\left(\mathrm{NH}_{3}-\mathrm{N}\right)$ & 21.0 & ND* \\
\hline Nitrate $\left(\mathrm{NO}_{3}-\mathrm{N}\right)$ & 3.6 & 18.1 \\
\hline Total Phosphorus & 4.5 & 3.8 \\
\hline $\mathrm{HCO}_{3}$ Alkalinity $\left(\mathrm{mg} / \mathrm{L}\right.$ as $\left.\mathrm{CaCO}_{3}\right)$ & 177.0 & 25.4 \\
\hline Total Alkalinity $\left(\mathrm{mg} / \mathrm{L}\right.$ as $\left.\mathrm{CaCO}_{3}\right)$ & 177.0 & 25.4 \\
\hline Biochemical Oxygen Demand (BOD) & 31.9 & 5.8 \\
\hline Total Organic Carbon (TOC) & 27.0 & 8.7 \\
\hline Total Dissolved Solids (TDS) & 661 & 473 \\
\hline Total Suspended Solids (TSS) & 40.7 & 20.8 \\
\hline Specific Conductivity (SC) $(\mathrm{mS} / \mathrm{cm})$ & 1030 & 739 \\
\hline $\mathrm{pH}$ & 7.2 & 6.8 \\
\hline Turbidity (NTU) & 16.7 & 6.2 \\
\hline Total Coliform (No./100 mL) & $10^{6}-10^{5}$ & $10^{4}-10^{5}$ \\
\hline
\end{tabular}

*ND - Not Detectable

15 
24 Table 2. List of tertiary treatment alternatives considered for use with secondary treated municipal wastewater (MWW) (Theregowda et al., 2013)

\begin{tabular}{|c|c|}
\hline $\begin{array}{l}\text { Abbreviations } \\
\text { RW }\end{array}$ & $\begin{array}{l}\text { Tertiary Treatment Processes Included } \\
\text { River water pumped from source and filtered }\end{array}$ \\
\hline MWW_F & Filtration $(\mathrm{F})$ only with addition of chemical conditioning agents \\
\hline MWW_NF & $\begin{array}{l}\text { Nitrification }(\mathrm{N}) \text { and filtration }(\mathrm{F}) \text { with addition of chemical conditioning } \\
\text { agents }\end{array}$ \\
\hline MWW_SF & Softening $(\mathrm{S})$ and filtration $(\mathrm{F})$ with addition of chemical conditioning agents \\
\hline MWW_NSF & $\begin{array}{l}\text { Nitrification }(\mathrm{N}) \text {, Softening }(\mathrm{S}) \text { and filtration }(\mathrm{F}) \text { with addition of chemical } \\
\text { conditioning agents }\end{array}$ \\
\hline MWW_NFG & $\begin{array}{l}\text { Nitrification }(\mathrm{N}) \text {, filtration }(\mathrm{F}) \text { and granular activated carbon }(\mathrm{G}) \text { treatment } \\
\text { with addition of chemical conditioning agents }\end{array}$ \\
\hline MWW_pH & $\mathrm{pH}$ adjustment $(\mathrm{pH})$ with addition of chemical conditioning agents \\
\hline WSI\&D & $\begin{array}{l}\text { Treated water delivery infrastructure (pipeline and pumps) and energy to } \\
\text { pump water to an average } 10 \text { mile distance between POTW and TPP }\end{array}$ \\
\hline $\mathrm{CW}$ & City water which has been treated for commercial and/or industrial use \\
\hline
\end{tabular}


Table 3. Input to the EIO and process-based LCA models to determine the inventory emissions

\section{Input Parameter}

Construction of infrastructure (in 2002 million USD)

Pump and pumping material manufacturing (in 2002 million USD)

Plumbing fixture fitting (in 2002 million USD)

Valve and fittings other than plumbing (in 2002 million USD)

Fabricated pipe and other pipe fitting manufacturing (in 2002 million USD)

Material handling/manufacturing equipment (in 2002 million USD)

Metal tank, heavy gauge manufacturing (in 2002 million USD)

*Electricity grid mix (in $\mathrm{kWh}$ )

*Transportation via road (in ton-km)

*Transportation via rail (in ton-km)

Landfill (ton)

Coal for GAC $(\mathrm{kg})$

Natural gas for GAC preparation $\left(\mathrm{Nm}^{3}\right)$

Steam for GAC preparation $(\mathrm{kg})$

* $\mathrm{HCl}$ for GAC preparation $(\mathrm{kg})$

*Hydrated lime for softening $(\mathrm{kg})$

*Sulfuric acid (100\%) (kg)

* Maleic anhydride for Polymaleic acid preparation $(\mathrm{kg})$

*Monochloramine (kg)

*Soda ash $(\mathrm{kg})$

${ }^{\mathrm{a}}$ Chemical manufacture for TTA $(\mathrm{kg})$

\section{Database/Model used for Inventory \\ EIO-LCA \\ EIO-LCA \\ EIO-LCA}

EIO-LCA

EIO-LCA

EIO-LCA

EIO-LCA

U.S.LCI, Franklin and Ecoinvent

U.S.LCI, Franklin and Ecoinvent

U.S.LCI, Franklin and Ecoinvent

Eco-invent

Franklin

Eco-invent

Eco-invent

U.S.LCI and Eco-invent

U.S.LCI and Eco-invent

U.S.LCI and Eco-invent

U.S.LCI and Eco-invent

U.S.LCI and Eco-invent

U.S.LCI and Eco-invent EIO-LCA

${ }^{\mathrm{a} A s s u m e d ~ a s ~ a ~ g e n e r a l ~ c h e m i c a l ~(d u e ~ t o ~ l a c k ~ o f ~ s p e c i f i c ~ d a t a ~ o n ~ m a n u f a c t u r e ~ p r o c e s s) ~}$

*Uncertainty analysis conducted for impacts, using available inventory data from other databases such as 
Table 4. Unit external (or social) damage estimates (1992, 2002 and 2010 USD) from air 45 emissions of environmental externalities

\begin{tabular}{|c|c|c|c|c|}
\hline \multirow[t]{2}{*}{ Species } & \multicolumn{4}{|c|}{$\begin{array}{l}\text { Estimated external costs (USD/kg } \\
\text { of air emissions) }\end{array}$} \\
\hline & $\min$ & median & mean & $\max$ \\
\hline${ }^{\mathrm{a}} \mathrm{CO}_{2}$ eq. (1992 USD/kg) & 0.002 & 0.014 & 0.013 & 0.023 \\
\hline${ }^{\mathrm{b}} \mathrm{CO}_{2}$ eq. (2010 USD/kg) & 0.001 & 0.011 & 0.032 & 0.105 \\
\hline${ }^{\mathrm{a}} \mathrm{SO}_{2}(1992 \mathrm{USD} / \mathrm{kg})$ & 0.77 & 1.8 & 2 & 4.7 \\
\hline${ }^{\mathrm{c}} \mathrm{SO}_{2}(2002 \mathrm{USD} / \mathrm{kg})$ & 1.28 & 13.4 & 11.2 & 114.6 \\
\hline${ }^{\mathrm{a}} \mathrm{NO}_{\mathbf{x}}(1992$ USD/kg) & 0.22 & 1.06 & 2.8 & 9.5 \\
\hline${ }^{* \mathrm{~d}} \mathrm{NO}_{\mathrm{x}}(2002 \mathrm{USD} / \mathrm{kg})$ & -0.8 & 1.75 & 2.3 & 8.6 \\
\hline${ }^{\mathrm{a}} \mathrm{PM}_{10}(1992$ USD/kg) & 0.95 & 2.8 & 4.3 & 16.2 \\
\hline${ }^{\mathrm{d}} \mathbf{P M}_{2.5}(2002 \mathrm{USD} / \mathrm{kg})$ & 1.9 & 17.9 & 33 & 197.1 \\
\hline
\end{tabular}

*Mid-level point source emissions

Data Source: a - Matthews and Lave, 2000; b -U.S. Government IWG, 2013;

c-Muller and Mendelsohn, 2007; d - NRC, 2010 